\title{
The dollar correction and the Asian currencies
}

\author{
Dilip K. Das \\ School of Business, Conestoga College, 299 Doon Valley Drive, ON N2G 4M4, \\ Kitchener, Canada \\ Tel: +1 519748 5220, E-mail: dilip.das@sympatico.ca
}

Received: 24th March, 2005

Dilip K. Das is Professor of International Economics at the School of Business, Conestoga College, Kitchener, Ontario, Canada. He was educated at the Graduate Institute of International Studies, University of Geneva. A professor of international trade and international finance and banking, he was associated with Webster University, Geneva; ESSEC, Paris and INSEAD, Fontenbleau, France; Australian National University, Canberra; and the Graduate School of Business, University of Sydney. He has published extensively on international trade, international finance, international business and globalisation related issues. His recent interests are in the Asian economy and the title of his most recent book is 'Asian Economy and Finance: A Post-Crisis Perspective' (Springer Publications, New York, NY, 2005).

\section{Practical applications}

Several significant practical applications emerge from this paper. The principal ones are as follows: First, present imbalances in the international economy which are reflected in the US current account and fiscal deficits, a measly rate of household savings and an overvalued currency need to be addressed without any further foot dragging. A flow of disturbing statistics regarding the US twin deficits has continued for a while now. In a globalising world economy what transpires in the US economy affects many others as well. The financial markets, central bankers and supra-national institutions like the IMF have expressed their concern repeatedly regarding these imbalances. Ostrichism needs to end and policy measures need to be devised by Ben Bernanke, the present Chairman of the FED, and the team of the Presidential advisers to bring about a rapid turnaround in this situation. The IMF's warnings of calamitous consequences must be taken seriously by the US policy mandarins.

The twin deficits inter alia have had an injurious effect across the manufacturing sector in the US and have been transforming the structure of the US economy for decades, causing the loss of jobs in the manufacturing sector. How long can US policy-makers ignore these long term structural effects? In particular, the rate of household, corporate and government savings in the US has had a declining trend since 1981. In the early 2000s it declined to its all time low level. This weakness also needs to be addressed on a priority basis. On the

Derivatives Use, Vol. 11 No. 4,2006 pp. 345-365 (c) Palgrave Macmillan Ltd currency valuation front, depreciation of the dollar needs to continue until the US current account imbalance declines, without a sharp fall in the growth rate.

The Asian currencies that followed a floating exchange rate regime during the post- crisis period, also intervened in their currency markets and tried to hold their currencies on a 
lower side than the free currency markets would allow. The frequency of market intervention was high, which caused their currency regime to turn into a 'managed float' instead of a free floating regime. Due to unremitting intervention by the central banks in Japan and the emerging-market Asian economies, central bank reserves nearly doubled in a short time span. There is a understandable lesson here for the central bankers in this set of economies. Although one of the important motives behind accumulating large foreign exchange reserves is protection against a run on the currency, the present level of reserves is far higher than that at the time of the Asian crisis. It can not only ward off a comparable crisis but also make the respective countries feel safe in terms of the level of reserves.

In the changed circumstances, the Asian economies began accumulating reserves in the process of preventing their currences from appreciating against the dollar and thus keeping their exports competitive in the global market place. This policy is rational for a while, but cannot possibly be made into a permanent policy stand without causing imbalances in the global economy, which in turn is sure to result in friction among economies.

The reluctance of the Asian central bankers to allow their currencies to appreciate vis-à-vis the dollar, or allow only slowly, has been criticised. The yen, renminbi yuan and the other Asian currencies need to appreciate without intervention to reflect their economic fundamentals. They need to float and find their own market-determined levels.

\section{Abstract}

Imbalances in the global economy emanating from the appreciation of the dollar, unnervingly large fiscal and current account deficits in the US economy, steeply rising foreign exchange reserve levels in Japan and the emerging-market economies of Asia created a worrisome policy environment for the global economy. Repeated warning signals were flashed by the International Monetary Fund (IMF) regarding these imbalances. This paper first delves into the causes and effects of the global economic imbalances. As the dollar correction began, the initial reaction of the central banks and the currency markets was tentative. With the continuance of the dollar correction, the global currency environment began changing. The second focus of this paper is on the impact of dollar correction on the three major Asian economies, namely the yen, the renminbi yuan and the won. It this context, it also analyses the recent currency devaluation of the renminbi yuan and the change in the exchange rate regime announced by the People's Bank of China and the implications of this change.

\section{CHRONIC IMBALANCES IN THE US ECONOMY}

By the end of 2004, the US economy had grown into something like a mirror image of the Asian economies of the crisis period. The imbalance in the current account, fiscal deficits, a measly rate of household savings in the US and an overvalued currency has been a long-standing concern of the financial markets and central bankers. US government finances have experienced a remarkable turnaround in recent times. Within only a few years, the hard-won 
gains of the previous decade were lost. The unified deficit swelled to $\$ 375 \mathrm{bn}$ in fiscal 2003 and continued to expand, reaching $\$ 412.6$ bn in fiscal 2004. This was the largest budget deficit in US history. It stood at 6 per cent of the gross domestic product (GDP) in 2004. ${ }^{1}$ Fiscal deterioration has not been restricted to the federal budget but has also taken place at the state and local government levels. As a result, the US general government deficit is now among the highest in the industrialised world and deficits are being projected for the foreseeable future. Under reasonable projections, the budget deficit is likely to amount to about 3.5 per cent of GDP in each year over the next decade. ${ }^{2}$ The International Monetary Fund (IMF) had warned of calamitous consequences on several occasions in the past, but these were ignored by the central banking authorities in the US. The twin deficits inter alia have had an injurious effect on the manufacturing sector in the US and have been transforming the structure of the US economies for decades.

The dismal forewarning could not be ignored forever, although, in the past, the Chairman of the Federal Reserve Board (Fed), Alan Greenspan, had believed that, in a globalised financial market, the ever-expanding US current account and fiscal deficits need not be treated as a grave problem because global capital inflows could fulfil the US deficits. These deficits were being continuously financed by foreign central banks, particularly those from the emerging Asian market economies, which held more than half the outstanding stock of US Treasury instruments. Greenspan also believed that brisk productivity growth in the US would attract global investors and capital inflows would continue ad infinitum.

The disturbing arithmetic of US trade is as follows. In round numbers, US exports have been 11 per cent of GDP, while imports 16 per cent. Thus exports are about two-thirds of imports. Or, imports are about 50 per cent larger than exports. The size of the US current account deficit (\$614bn, adding up to 5.7 per cent of the GDP at the end of 2004) was alarmingly high. It represents over 1 per cent of the global GDP and absorbs approximately two-thirds of the cumulative current account surpluses of all the surplus countries in the world. All these figures are without precedent. Relative to the global economy, no single nation's deficit has ever bulked nearly as large. Recent modelling exercises have addressed the future level of deficits. The 'OECD Economic Outlook' projected the US current account deficit to reach $\$ 825$ bn in 2006 , or 6.4 per cent of the GDP. ${ }^{3}$ The OECD projections assumed unchanged exchange rates. Roubini and Setser ${ }^{4}$ predicted it to reach 6.5 per cent of the GDP by 2006, and 7.8 per cent in 2008. It is easy to see that, without some form of discontinuity, the deficit will not increase further from its current high level.

Lurking behind these perturbing statistics is another more disturbing trend. In 1969, Houthakker and Magee studied income and price elasticities in world trade and found a growing US demand preference for imported products. Elasticity of US exports with respect to growth in the rest of the world (ROW) was found to be less than 
the elasticity of US imports with respect to domestic economic growth. That is, domestic growth in the US economy was found to suck in more imports than growth in the ROW was found to suck in US exports. This is a structural trait of the economy and became known as the Houthakker-Magee effect. Thus, the US faces unfavourable income elasticity in trade. Although there was a surplus in 1969, based on the computations of elasticities, Houthakker and Magee ${ }^{5}$ predicted a secular decline the US trade balance, which has come true. This anomaly was predicted to disappear in three decades, which has not happened.

There is a deficit-does-not-matter group of economists in the US that defended the large deficits and preferred to take it in their stride for the following reasons. First, according to them, large deficits were a sign of the strength of the US economy, not a symptom of macroeconomic or financial debility. Their logic was that the US is an economy that external capital is trying to get into, not one from which it is trying to flee. The inward capital flow was taken as an indicator of macroeconomic strength. Secondly, they put the cart in front of the horse by arguing that it was sluggish demand in the emerging Asian market economies and the European Union (EU) that was responsible, at least in part, for the large US deficit, not the profligacy of the US consumers. Therefore, they believed that the deficits could be reversed when a pressing need to do so arose. Thirdly, the large current account deficit has been caused by the trade of transnational corporations (TNCs) with their foreign subsidiaries.
Fourth, it is in the interest of the Asian central banks to purchase US Treasury bonds, which have traditionally financed the US deficits. Their purchase of Treasury bonds maintained their own currencies at a low level, which in turn supported their own export-led growth. As the dollar is the largest reserve currency, its demand from the central banks helps in creating a stable global economic system. None of these arguments is irrefutable.

The deficit-does-not-matter group also pointed to the economies that built up higher debt ratios than the US, namely, Australia and New Zealand. They argued that, as these two economies did not suffer from any adverse consequences of massive external debt, why should the US economy. The irrelevance of this argument is that these two economies are hardly comparable to the US because their current account deficit absorbs only a minuscule proportion of global savings. According to the Economic Intelligence Unit (EIU) (2004) estimates, in 2004 alone the US net borrowings 'will mop up a massive 75 per cent of the world's surplus saving'. In recent years, the US's largest bilateral trade deficit has been with China. Asia as a whole accounted for half of America's total trade deficit.

\section{Saving shortfall in the USA}

The rate of household, corporate and government savings in the US has been in decline since 1981, when it had reached a high of 12.5 per cent of GDP. In the five years from 1999 to 2003, the net national savings rate remained around 1.5 per cent, 'the US has recorded the lowest net 
national savings rate in the American history'. 6 US consumption growth averaged 3.9 per cent over the 1996-2004 period, which was almost double the 2.1 per cent average increase in the industrial countries. In the first seven months of 2004, household savings in the USA slumped to just 0.7 per cent, and in October 2004 it was 0.2 per cent. This lack of savings was readily reflected in the current account deficit. Meagre saving also forced USA firms to borrow abroad. A disturbing characteristic of external capital inflows of the recent years in the USA was that it did not always finance productive investment but went into a consumer spending binge and a growing budget deficit. Had it been channelled into investment, it would have lifted future income flows. A current account deficit that reflects a lack of saving manifests macroeconomic economic weakness, not strength.

One injurious consequence of the saving shortfall and tax cutting orgy in the USA was the transformation of the structure of the US economy by accelerating its deindustrialisation. ${ }^{7}$ This structural transformation has been accelerated since the mid-1960s. Employment in the US manufacturing sector as a share of the labour force has fallen further and faster than in other industrial economies. In 1965, manufacturing output was 27 per cent of gross national product (GDP) and manufacturing's share of employment was 24 per cent. By 2003, corresponding proportions had fallen to about 13.8 per cent and 10.5 per cent, respectively. In 2004, the US manufacturing sector operated at 78 per cent of capacity.
Employment in the manufacturing sector is likely to continue to remain weak. There was another channel of injurious effect on the manufacturing sector. A rising level of current account deficit takes place more through import of goods than of services. Although ICT services were being outsourced to India, services in general are not so easily traded internationally. When US spending rises above the domestic output level, the net absorption of foreign goods - essentially manufactures contributes to shrinkage in the US manufactured goods sector.

When US firms or households purchase manufactured goods, their spending is neutral to the fact of whether the goods are produced at home or abroad. Domestic production shrinks by the amount of the trade deficit in manufactures. Consequent job losses also depend on labour productivity in manufacturing, which has risen strongly over time. If the trade deficit in manufactures is added to domestic production to get 'adjusted manufactured output', one can compute manufacturing employment level. McKinnon ${ }^{7}$ computed that, in 2003, actual manufacturing employment was just 10.5 per cent of the US labour force, but it would have been 13.9 per cent without a trade deficit in manufactures. The difference - at 4.7 million lost jobs - is significant. This computation was based on the assumption of constant labour productivity. Although in the long run the growth in service employment will largely offset the decline in the manufacturing sector, a pressing need for short- and medium-term adjustments persists. 


\section{Depreciation of the dollar}

The dollar appreciated consistently from the mid-1990s. Between May 1995 and January 2002, its nominal effective exchange rate (NEER) appreciated by 44.5 per cent and the real effective exchange rate (REER) by 34.0 per cent. The REER indices of a currency are trade-weighted real exchange rates against a basket of currencies. This appreciation was not supported by fundamentals and was unsustainable. In January 2002, the current account deficit of the US had grown to 4.4 per cent of GDP. High and growing twin deficits, a paltry rate of household savings and numerous accounting and financial scandals on Wall Street coalesced to trigger a selling pressure on the dollar, which peaked in February 2002, beginning a long dollar correction or currency realignment period, which is still continuing. The depreciation of the dollar has been uneven vis-à-vis various important currencies. Between February 2002 and June 2003, it depreciated most $(20+$ per cent) against the euro but only 10 per cent against the yen. Against other Asian currencies, it depreciated even less and its rate against the renminbi yuan remained unchanged at 8.28 to the dollar.

In the latter half of 2004, the volume of financial flows in the US began to decline. Portfolio inflows continued but at a slower pace than in the first half. In August and September 2004, financial inflows were below the monthly average level of the first half of the year. At the end of the third quarter of 2004, concerns regarding the long-standing and growing imbalances were renewed, causing the dollar to depreciate further. Market expectation was of a continuing medium-term depreciation of the dollar, although it could not possibly be a disorderly depreciation, or 'hard landing'. The reasons were, first, strong productivity growth in the US economy and, second, continuing demand for US assets from Asian central banks, albeit at a lower level than in the past. The dollar depreciated further in October 2004. Financial inflows largely went into the US Treasury and corporate bonds, which kept yields and credit spreads low.

In the latter half of November 2004, Chairman Greenspan turned bearish and reckoned that capital inflows might not continue for ever. If they did, investors may in future demand a cheaper dollar, or cheaper assets, or both, to carry on financing US deficits. For the first time, he described the US current account deficit as 'increasingly less tenable'. Greenspan's comments of 19th November in Frankfurt, Germany were a belated admission that capital inflows not only might not last ad infinitum, but also that the problems of the US economy were home-grown. Alan Greenspan, whose observations on the economy are taken rather seriously by the global financial markets, said in a speech on 19th November, 2004, at the European Banking Congress in Frankfurt, Germany: 'Current account imbalances, per se, need not be a problem, but cumulative deficits, which result in a marked decline of a country's net international investment position - as is occurring in the US raise more complex issues. The US current account deficit has risen to more than 5 per cent of GDP ... Given the size of the current-account deficit, a diminished 
appetite for adding to dollar balances must occur at some point.'

There was an immediate impact of this candid, first-ever admission of weaknesses in the US economy by the Chairman of the Fed. The dollar went into precipitous depreciation vis-à-vis all the major currencies on 20th November, 2004, although it was lopsided. The euro appreciated far more against the dollar than did the yen and the other Asian currencies. It rose to $\$ 1.32$ for the first time in the life of the single European currency. Sterling appreciated to $\$ 1.88$ and the yen to Y104 to the dollar. By this time, the dollar had depreciated to a new all-time low level against the euro and a five-year low against the yen. In three years, since the beginning of the dollar correction period (in February 2002), the dollar lost a total of 35 per cent against the euro and 24 per cent against the yen; but it had depreciated by a more modest 17 per cent against a broad basket of currencies, which included the renminbi yuan and the other Asian currencies. The won recorded an appreciation of 14 per cent against the dollar in 2004 alone. The won/dollar exchange rate of 1065.30 was a seven-year low level.

At the end of December, the euro further appreciated to $\$ 1.36$, but the value of sterling (\$1.92) and the yen $(¥ 103.62)$ did not change much. The won/dollar rate appreciated further to 1047.80. Larger appreciation of the euro vis-à-vis the dollar reflected the fact that the European Central Bank (ECB) did not intervene in the currency markets. Jean-Claude Trichet was known for his strong belief in the strength of currencies even before he became the president of the ECB. As president of France's central bank in the years before euro entry, he was hailed as 'the ayatollah of the franc fort' for his steady support of a strong national currency.

Furthermore, the ECB had made it clear that it had no plans to intervene. Although after March 2004, the Bank of Japan (BOJ) also did not intervene, the currency markets were aware that it could if the yen began to appreciate at a rapid pace. By the end of December 2004, on a broad trade-weighted basis, the REER of the dollar had declined by 15 per cent from its peak in February 2002. This was computed by the Morgan Stanley Global Economic Forum, "How to Fix the World: Looking to 2005', on 17th December, 2004. This depreciation was generally regarded as inadequate. Fundamentally, a larger dollar correction was warranted, therefore depreciation was likely to continue in 2005. On 17th January, 2005, the dollar depreciated further vis-à-vis the yen ( $¥ 101)$, although at this point it had stabilised against the euro at 1.309. A broad range of empirical studies that were conducted in mid-2004 concurred that the dollar had a substantial adjustment to make. Estimates made by Obstfeld and Rogoff 9 indicated that adjustment in the US economic imbalances would require a 25 per cent depreciation of the dollar. At the same time, Goldman Sachs ${ }^{10}$ estimated that a 30 per cent decline in the value of the dollar would be needed just to stabilise the net international investment position (NIIP) at -55 per cent of total GDP. Mann ${ }^{11}$ argued that a 10 per cent per 
year depreciation was needed just to keep the current account deficit stable over the foreseeable future.

Depreciation of the dollar needed to continue until the US current account imbalance declined, without a sharp fall in the growth rate. It was necessary if consumer spending on imported goods was to be reduced without a recession-inducing reduction of consumer spending on domestic goods. Also, domestically produced goods had to become relatively cheaper in the international market place to give a boost to US exports, so that the current account deficits could be reduced. It must be emphasised that reducing - not eliminating - the current account deficit is a realistic and pragmatic target. It needs to be reduced to a level that is sustainable in the medium term. With its higher productivity growth and younger population, the US economy can sustain a deficit of 2-3 per cent of GDP. This implies that the US Treasury needs to cut the deficit by approximately 3 percentage points, with corresponding adjustment among the surplus economies. ${ }^{12}$ Given the right macroeconomic policies and flexibility, the supply-side response to the depreciation rationally could be expected to reduce the current account deficit.

Uneven depreciation of the dollar vis-à-vis the currencies of major trading partners has been conspicuous. Over the entire dollar correction period (that is, between February 2002 and December 2004), the Federal Reserve's major currencies index fell by less than 30 per cent, while the broad index (which includes Asia - excluding the yen - and
Latin American currencies) fell by 15 per cent. It was widely recognised in the currency markets that, if there was to be a significant effect on the US current account deficit, a broader range of currencies needed to appreciate against the dollar. Large appreciations of the euro, the yen and the sterling were hardly enough on their own. As a significant proportion of the US current account deficit was vis-à-vis the Asian economies rather than against the European ones, it was logical to expect that the dollar should depreciate more against the former set of currencies than it had thus far. ${ }^{13}$ After the rounds of depreciation against the euro, the yen and, to a smaller extent, against the Asian currencies, in November and early December, 2004 the dollar looked overvalued against the baht, the peso, the ringgit, the Singapore dollar, the New Taiwan dollar and the won. The Indonesian rupiah was an exception in this respect.

\section{CLIMBING FOREIGN EXCHANGE RESERVES IN THE ASIAN CENTRAL BANKS}

The Asian currencies that followed a floating exchange rate regime during the post-crisis period theoretically should not have intervened in their currency markets and tried to hold their currencies lower than the free currency markets would allow. The monetary authorities in these economies did intervene frequently, causing their currency regime to turn into a 'managed float' instead of a free-floating regime. Owing to frequent and intense intervention in the currency 
markets by Asian central banks, their currencies first became quasi-fixed and then foreign exchange reserves began to swell at a rapid rate. Owing to unremitting intervention by the central banks in Japan and emerging Asia markets, reserves with the global central banks nearly doubled in a short time span. They climbed from $\$ 2$ trillion in 2000 to $\$ 3.5$ trillion in 2004. Also, Asia's (Japan, China, Taiwan, Korea, Hong Kong SAR) foreign exchange reserves had swollen from less than $\$ 800$ bn at the start of 1999 to over $\$ 1.83$ trillion by July 2004, which was more than half the global foreign exchange reserves. A comparison with the 12 Eurozone economies is essential to put these statistics in perspective. During the same period, the foreign exchange reserves of the Eurozone did not show any dramatic change. They fell slightly from $\$ 235 \mathrm{bn}$ to $\$ 225.9 \mathrm{bn}$. Instead of intervening in the currency markets, the ECB preferred the euro to appreciate against the dollar.

Dollar reserves are conventionally held in the US Treasury and corporate bonds by the global central banks. At the end of 2004, Japan had the maximum investment in the US Treasury instruments. The BOJ bought more US Treasury bonds than any other central bank has ever done. It had the equivalent of $\$ 820 \mathrm{bn}$ in foreign exchange reserves, most of it in the US Treasuries. Among the People's Bank of China's (PBOC) over $\$ 610$ bn foreign exchange reserves, 80 per cent were dollar assets or US Treasury securities. At the end of 2004, China's foreign exchange reserves were $\$ 609.9 \mathrm{bn}$, over $\$ 200 \mathrm{bn}$ higher than a year before. At the end of 2004, Taiwan's reserves were $\$ 239 \mathrm{bn}$, again a large part in US Treasuries. Following Japan, China and Taiwan, the other Asian emerging market economies also invested large amounts in US Treasuries. The central banks of Korea and Hong Kong SAR were also large buyers of US Treasury securities. The emerging market economies of Asia and developing Asia had $\$ 1.4$ trillion of foreign exchange reserves, again mostly in US Treasuries. This is more than the combined reserves of the rest of the world (excluding Japan).

The basic theoretical reason behind accumulating large foreign exchange reserves is protection against a run on the currency. Asian economies had to suffer it during the Asian crisis. The crisis-stricken economies nearly exhausted their foreign exchange reserves in their desperate endeavours to prop their currencies up. In the aftermath of the crisis, the Asian economies had become overly cautious and started attaching a great deal of significance to building up large reserves. They came to believe that these reserves were necessary to ward off any future crises.

By the end of 2004, Asian countries had accumulated far more reserves than could be justified by their earnest crisis prevention motive. A new motive took its place. The Asian economies began accumulating reserves in the process of resisting appreciation of their currencies against the dollar and thus kept their exports competitive in the global market place. This became the guiding motive behind their adhering to an inflexible stance regarding their currency valuation. Dooley 
et al. referred to this arrangement as 'the new Bretton Woods system' or 'Bretton Woods 2' ${ }^{14,15}$ These Deutsche Bank economists posited that the global economy had returned to the system of fixed exchange rates pegged to the dollar. It is similar to the Bretton Woods regime that worked between 1945 and 1973. The new Bretton Woods regime, according to them, would allow the US to finance its massive deficit at a low cost for a long while. They were, however, soon proved wrong because their argument was flawed. This so-called new Bretton Woods was not a global exchange system of fixed exchange rates. It applied merely to a region - Japan and the emerging Asian market economies. Besides, it was a quasi-fixed exchange rate system, which was neither sustainable nor stable.

The question of whether the foreign exchange reserves of the central banks of the emerging Asian economies - in particular, those of Japan, China and Taiwan - had not become excessive was being asked. These reserves were not without cost. The return on US Treasury instruments is usually low, certainly much lower than could be had from investing the financial resources more productively in the domestic economy. Also, large inflows of foreign exchange tend to bring too much liquidity into the economy, which causes asset-price bubbles. Asian central banks had tried to sterilise the inflows of foreign exchange and sold bonds to mop up extra liquidity in the domestic markets but, as reserves grew larger, sterilisation was fast becoming an increasingly difficult and unjustifiable option to take.

\section{GLOBAL IMBALANCE AND THE DOLLAR CORRECTION}

The preceding section stated that, as the recovery of Asian economies was essentially export-led, policy makers were reluctant to let their currencies compete freely. As the Asian economies competed against each other in third-country markets, they wanted to preserve the competitiveness of their exports in the Organization for Economic Cooperation and Development (OECD) and Asian markets. During this period, the global economy was in unstable equilibrium. The worry among the Asian economies was that, if they passively allowed their currencies to appreciate, they could find themselves in an unstable equilibrium in which Asian economies would be characterised by low growth, deflation and overvalued currencies. Over the years, Asian economies had made themselves into successful manufacturing economies. It was well within the realms of possibility that strong currencies would cause their de-industrialisation, which could boost their capital surpluses and makes overvalued currencies even stronger. ${ }^{16}$

The twin deficits were referred to as 'global imbalance' by Summers. ${ }^{6}$ Going one step further, Mann ${ }^{11}$ proposed a 'global rebalancing' for narrowing the US current account deficit on the one hand and widely distributed but persistent dependence of the rest of the world on net exports to the US, on the other. In order to resolve the currency conundrum, some academics and policy makers recommended a modern-day 'Plaza Accord' for Asia, with Asian countries cooperating to allow their currencies to appreciate against the dollar, 
paralleling the 1985 Accord among the Group-of-Five (G-5) countries that had reduced the US current account deficit. This was a well-coordinated macroeconomic exercise that led to a large appreciation of the yen and realignment of the Deutsch mark, the French franc, sterling and the lira.

The disinclination of Asian central banks to allow their currencies to appreciate vis-à-vis the dollar, or to allow it only slowly, was criticised during the conference of finance ministers from Asia and Europe in Bali, Indonesia, during July 2003. The European finance ministers urged their Asian counterparts to let their currencies appreciate without intervention. The IMF and the Bank for International Settlements (BIS) also called for a stronger renminbi yuan and appreciation of Asian currencies. In addition, governments in Europe and the US firmly believed and coaxed their Asian counterparts to let their currencies, in particular the yen and the renminbi yuan, to float and find their own market-determined levels. The eagerness of the European governments was easy to comprehend. As the dollar was depreciating in an asymmetrical manner, it was depreciating far more against the euro than against the other currencies.

Non-cooperation of Asian policy makers would logically create greater market pressure on the euro to appreciate against the dollar.

At the time of the Bali conference, many Asian currencies were competitive. As the dollar correction continued, the trade-weighted values of Asian currencies against a basket of currencies were continuing to fall. At this point, the renminbi yuan was more than 20 per cent undervalued against the dollar. One tell-tale symptom of undervalued currencies was an unusually fast rise in foreign exchange reserves. China, Japan, Taiwan and India had all recorded an unusually rapid rise in the levels of their reserves.

The September 2003 Group-of-Seven (G-7) meeting again called for the downward adjustment of the dollar vis-à-vis the yen and the Asian currencies. The G-7 communiqué advocated that 'flexibility' in exchange rates was desirable for major economies and regions for a smooth market-determined adjustment in currency values to take place. The message in this polite statement was that Japan, China and other Asian economies had built up large current account surpluses and foreign exchange reserves by resisting currency appreciation. Therefore, this communiqué suggested, this set of economies should appreciate their currencies to reduce global imbalances. Japan followed the advice and the yen began to appreciate against the dollar after September. The 'World Economic Outlook' of September 2003, after a long empirical discussion, warned that: 'Reserves in the emerging economies of Asia are now at the point where some slowdown in the rate of accumulation is desirable from both domestic and multilateral perspectives'. ${ }^{17}$

When the G-7 finance ministers and central bank governors met again in February 2004, their communiqué once again emphasised the need for more 'flexibility' in exchange rates from economies that had not adopted it at that point in time (published on 8th February, 
2004). They implied that the Asian economies, particularly the renminbi yuan that had not heeded the preceding G-7 call, needed to appreciate or float in the short term.

The Group-of-Twenty (G-20), was created in 1999 by the joint endeavours of Canada and Germany. It brought together the finance ministers and central bankers from the leading industrial, oil-exporting and emerging-market economies. The EU is an additional fully fledged member of this group. The G-20 convened its fourth meeting on 20th November, 2004, in Berlin. At this point, the dollar had once again come under intense selling pressure. The G-20 met against the backdrop of a sharply depreciating dollar and rising tensions in the global economy. The G-20 communique noted that a move into Asian currencies was obvious and the Asian crisis of 1997-1998 was repeating itself, only in reverse.

During the period of reversal of the Asian crisis, all the major Asian currencies, except the renminbi yuan and the Hong Kong dollar, appreciated. The implications of the reversal of the crisis on the three major Asian currencies were as follows.

\section{Implications for the yen}

After four successive recessions and a prolonged period of deflation, concern regarding export performance was valid. Japan was anxious to hold down the appreciation of the yen to keep its exports competitive in the global market place, particularly in the Eurozone and in Asia. The yen was allowed to appreciate gradually after the G-7 meeting of
September 2003 however. Being the second largest global economy made it imperative Japan be a responsible global citizen as well. During the third week of November 2004, when there was strong selling pressure on the dollar and buying pressure on the yen, the yen appreciation moved at a brisker pace than in the past. On 17th November, the spot rate for the yen reached $¥ 104.26$ to the US dollar, its highest point since April 2004. It rose further to $¥ 102.6$ to the dollar in late November, its highest point in almost five years. In December 2004, it hovered at the same level. The currency markets expected another dollar purchase binge from the monetary authorities in Japan, like the one they had seen in late 2003 and early 2004. The monetary authority had intervened in the past against its own currency because the Ministry of Finance (MoF) considered it important to prevent the yen from appreciating too far or too fast against the dollar. From January 2003 to March 2004, the BOJ spent a staggering $¥ 35$ trillion buying dollars — a sum equivalent to $\$ 302 \mathrm{bn}$ at last year's average exchange rate of $¥ 115.9$ to the $\$ 1$. This was done in accordance with the MoF's plan.

Although exports directly accounted for less than 15 per cent of Japan's GDP, export-oriented manufacturing has been one of the most dynamic sectors of the economy. Brisk export growth directly affected GDP growth in the real sector and indirectly supported the revival in private consumption and business investment. Although corporate restructuring had significantly contributed to Japan's much-needed economic recovery, 
intervention by the monetary authority in the currency markets was certainly worthwhile. Its principal achievement was the yen's considerably slower appreciation against the dollar in 2003 and 2004 than that of the euro. This contributed to strengthening the competitiveness of Japanese exports in the 12 Eurozone economies. It also made them more competitive compared with European exporters in the global markets outside the Eurozone.

Although the recovery had set in, the GDP data for the third quarter of 2004 indicated that Japan's export momentum had begun to wilt. Having grown by an average of 4.4 per cent quarter on quarter in the three preceding periods, in the three months to September exports of goods and services increased by a paltry 0.4 per cent and barely made any contribution to overall GDP growth. To be sure, weakening demand in global markets was an important factor. The fact that the yen had again breached the psychologically important $¥ 105$ to the dollar mark — a threshold beyond which it was believed that Japanese exporters would struggle to compete made it imperature to watch the exchange rate strategy carefully.

The flipside of the coin was that a decade-long deflationary phase had left its microeconomic mark on the Japanese economy and firms. They were prepared to cope with currency appreciation. First, the deflation of recent years muted the impact of currency appreciation on exporters, because a period of falling prices enabled Japanese firms to keep their domestic costs low. Secondly, Japanese companies - in particular, large export-oriented manufacturers - became better insulated against currency movements during the deflationary period. Also, exporters became adept at more sophisticated hedging techniques than they were used to in the past. Thirdly, large exporters, like car makers, had moved increasing amounts of production offshore. In many cases, entire facilities were moved to the final destination markets for which the products were being manufactured. Such strategies removed currency movements as a variable affecting sales, although they affected the value of profits repatriated to Japan. Fourthly, many Japanese exporters had begun purchasing and invoicing in yen, which reduces their exposure to exchange rate risk. Japanese companies exporting equipment to subsidiaries in China and other parts of Asia, for instance, routinely invoiced in yen. Therefore, by the time the yen appreciated, Japanese exports were better cushioned against currency appreciation than in the past.

\section{Implications for the renminbi yuan}

The de facto dollar peg of 8.28 renminbi yuan to the dollar was established in 1994, after a currency devaluation of 28 per cent. Speculators in the currency markets had been betting on the revaluation of the renminbi yuan since the beginning of the dollar correction period in February 2002. Consequently, speculation was rife in the currency markets. Expectations of a revaluation became stronger after the official statements regarding China's flexibility towards currency reforms and a series of small deregulationary measures 
taken by the PBOC. These measures included allowing: foreign trading companies to retain, in full, their foreign exchange incomes in foreign exchange accounts; insurance companies and pension funds to invest overseas; Chinese emigrants to transfer their assets out of China; and Chinese tourists and students to take larger amounts of hard currency out of China.

A one-off currency revaluation, a floating regime and pegging the currency to a basket of currencies were seen by economists as logical options open to the monetary authorities, because it was believed that they would be helpful in combating inflationary forces and in lowering the cost of commodity imports for China's huge recent demand growth, which hardened commodity prices in the global market place. Revaluation under these circumstances would have a meaningful payoff for the Chinese economy. China could take note of the US quandary and revalue its currency to help bring down its massive current account deficit. After the sharp depreciation of the dollar began in November 2004, market expectations of a renminbi yuan revaluation increased further. Market participants believed that China might maintain its peg until early or mid-2005 and then revalue, float or peg the currency to a basket. Only Morgan Stanley believed that the renminbi yuan-dollar peg might continue until late 2005. ${ }^{13}$ Whenever the decision to revalue the renminbi yuan is taken, if it is appreciated substantially, the currencies of Asia's emerging markets could be expected to follow suit in a full round of currency appreciation. The magnitude of their appreciation would necessarily be smaller than that of the renminbi yuan, because these currencies allowed appreciation after the February, 2004 meeting of the G-7. A small appreciation of the renminbi yuan of say, 5 per cent or less - may not lead to this full round of currency appreciation, however. In addition, if such a round of currency appreciations did take place, it would certainly depreciate the dollar further vis-à-vis a broad basket of the Asian currencies.

Contrary to market expectations and speculative pressure, the PBOC did not see any pressing or immediate need to disturb its de facto dollar peg. This peg had served the Chinese economy well since its inception, which made it all the more necessary for the PBOC to be extra cautious with regard to switching to a new currency regime. As indicated above, the options are: adopting a managed float, pegging to a trade-weighted basket and pegging to a basket and adopting a wide band within which the currency can fluctuate. It could range between +10 and -10 per cent from the peg. If the new regime - be it a managed float or pegging to a basket - does not serve the economy well in the medium-term and causes disruptions, it could be readjusted. Currency appreciation of, say, 10 per cent would be seen as a potentially serious disruption to exports and unemployment rate. Employment generation is one macroeconomic policy area where China has performed poorly. While China's economy was growing at the highest annual growth rate of any of the world's principal economies (9.3 per cent in 2003, 9.5 per 
cent in 2004 and in the first half of 2005), its increase in employment was only 1 per cent annually. For political, social and economic reasons, generating job opportunities for large numbers of unemployed and underemployed workers, and achieving a high rate of job creation, is no less important than achieving high real GDP growth targets. Official unemployment statistics provide a sanitised, incomplete and somewhat misleading, picture of reality.

China is a large exporter of manufactured goods, a sector known to employ a large proportion of the labour force. Currency appreciation or float would certainly, therfore, adversely affect exports and employment. The larger the magnitude of currency appreciation, the greater would be the disruption. China's comparative advantage would certainly change with currency appreciation and it might even be forced out of several low-, medium- and high-technology product lines by other nimble and dexterous Asian economies, which have also been successful exporters in their own right.

A poorly planned currency appreciation may even lead to worse consequences. In 2004, the Chinese economy suffered from several sectoral price bubbles. The most conspicuous were the bubbles in the property, steel, cars, heavy chemicals and cement sectors. A currency appreciation could possibly pop these bubbles, not only triggering a domino effect in the rest of the economy but also adversely affecting the other Asian economies. Creation of a Japanese-like deflationary situation would become a high probability. Therefore, it was far from optimal for the PBOC seriously to contemplate a currency revaluation in the short-term. Furthermore, China's financial market infrastructure is too deficient to cope with an appreciable change in the currency regime. A prerequisite for moving towards currency flexibility, say a floating exchange rate regime, is the depth of the derivative market and the availability of hedging products. China faces serious deficiencies in both these areas.

Yet another fragility of China's financial sector was the heavy burden of non-performing loans (NPLs), making it an inappropriate time for a major shift in the currency regime. The four largest state-owned commercial banks have been under a large burden of NPLs. Approximately half their assets are considered to be impaired, which puts the financial system in a delicate state. Although efforts to repair the system have been under way for a while, they are not as rapid and sure footed as the credit-rating agencies would wish. (This is according to an estimate made by Standard \& Poor that $\$ 656$ bn was needed to resolve the NPL problem of these four largest banks, published on Bloomberg.com on 30th November, 2004. ${ }^{18}$ )

During the Asian crisis, China did not depreciate its currency - when it was widely expected to do so - and won international acclaim for its professionalism, clairvoyance and goodwill for the neighbouring regional economies. China let the international financial community know that it was a responsible player in the global financial 
markets and earned the confidence and commendation of international investors. While China was aware of the international community's need to let the renminbi yuan appreciate or float, the PBOC rode out the international pressure because an undervalued currency is inter alia easier to manage than an overvalued one. In the medium term, an undervalued currency delivers better-quality economic growth by providing momentum to exports, generating current account surplus, building up foreign exchange reserves, which can be put to a myriad of uses. At a later stage, exports can adjust to an appreciating exchange rate by moving up the value-added chain. Conversely, an overvalued currency delivers lower-quality growth and creates economic bubbles by encouraging excessive external borrowing.

Although China has been bringing in gradual currency reforms (as stated above) they did not seem to be part of a strategy of short-term currency appreciation. From the Chinese perspective, reform of the currency regime and capital account liberalisation seems to be a medium-term policy objective, not a short-term necessity. The monetary authorities never give an impression of taking on additional risks of a major shift in currency regime. In the short-term, macroeconomic and financial policy management and reforms keep the agenda of the policy mandarins full. The currency markets' expectations of a revaluation, although rational, did not pan out for a long while.

Conditional upon a reduction in speculative pressure and the government's policy measures to rectify the macroeconomic and financial limitations, market participants expected a shift in the currency regime, in the form of either a renewed peg or a link to a currency basket, in 2005. This expectation came true after the meeting of the G-7 finance ministers and central bankers in the first week of February, 2005. (China was invited to the G-7 meeting which took place in London on 5th February, 2005. Chinese central bank deputy governor Li Ruogu told reporters after the meeting: "We are determined to move towards a flexible exchange rate', although a timeframe of future events was not available at that point.)

The PBOC announced that it was preparing to peg its currency to a basket of currencies in lieu of the dollar, although it would take China much longer to determine the value of the currency by market forces. On 21st July, 2005, the renminbi yuan was revalued by 2.1 per cent against the dollar, its new value being 8.11 to the dollar. Also, the dollar peg was abandoned and replaced by a managed float against a basket of undisclosed currencies. The trading band was relaxed from \pm 0.1 per cent to \pm 0.3 per cent. The announcement of revaluation and change of currency regime created a shockwave in the global, currency, bond and commodity markets.

This adjustment in the currency value was much smaller than market participants expected. It was also too small to have any major macroeconomic impact. Rapid GDP expansion will not be dampened by it. The shift to a currency-basket peg will increase 
China's monetary flexibility for managing the economy. The combination of the small revaluation and the shift to currency-basket pegging signalled that more monetary reforms may be in the offing. They should increase international confidence in the Chinese economy and, hence, be conducive to more long-term capital inflows into both China and Asia, and increase demand for Asian assets. As the new system is called a 'managed floating exchange-rate regime', it may well mean that it would be more managed than floating. To be sure, the revaluation is small; it is the start of a series of further renminbi yuan revaluation that will bring an alignment of other East Asian currencies by pushing them upwards against the dollar to correct the global, particularly the US, trade imbalances. The eventual economic and political effects of the revaluation will depend on how far and how fast the renminbi yuan moves from now on.

Monetary authorities managed the soft landing that they were aiming for well. At the time of revaluation, the economy looked well balanced. It was getting more support from consumer spending, alongside fixed investment and exports. Rising household incomes were boosting households' spending power, lifting retail sales by 13 per cent in the first half of 2005 , compared with the same period in 2004. The agricultural sector began playing its role. After six years of lacklustre growth, rural incomes rose by 12.5 per cent in the first half of 2005.

The managed floating exchange rate adopted by the PBOC was not an original Chinese concept. Singapore has used it since the early 1980s. This system was christened the 'basket, band and crawl' or the BBC. The currency is managed against an undisclosed basket of currencies of the largest trading partners. In this system, the exchange rate floats within a band, which allows the currency to crawl up or down instead of sharply fluctuating. The BBC is considered one of the most successful currency regimes in the world. It provided the Monetary Authority of Singapore (MAS) with the flexibility to respond to changes in both local and global conditions and simultaneously maintain export competitiveness and inflation control.

The composition of the currency basket is revised periodically to take into account changes in trade patterns. The secret policy band is also reviewed regularly to ensure it remains consistent with changes in the economic circumstances. It is adjusted every two quarters or every quarter, if needed. Singapore has guided monetary policy through exchange rates instead of directly adjusting interest rates. Inflation has been relatively low at 2 per cent a year since the early 1980s. More Asian economies could use the BBC system as a template.

\section{Implications for the won}

Korea is Asia's third largest economy, and what happens to its currency is of consequence to the region. Owing to the balance of payments problem during the Asian crisis, Korea was forced to depreciate the won precipitously. Soon thereafter, the won was virtually pegged to the yen. Its trading range changes from time to time, but the won/yen cross-rate is far less volatile than the won/dollar rate. The won 
exchange rate is essentially based on the yen. It was thoughtfully done with a view to promoting future export growth. For a large range of products, Korean exports overlap with those of Japan, although in terms of value and volume they are much smaller. In most of these products, Korean export prices are more competitive than those of the Japanese, which has allowed Korea to expand its market share. In the recent past, much of the domestic economy and demand in Korea has remained frail. In 2003, Korea recorded a real GDP growth rate of 2.4 per cent, which was disappointingly low. Unlike domestic consumption and investment, export performance was robust, with an annual growth rate of 16 per cent. Thus, the GDP growth rate in 2003 was essentially export driven. The GDP growth rate in Korea was far more export driven than in China and Japan.

The Korean economy was therefore highly vulnerable to a deceleration in export growth rate. Its vulnerability was sure to be exacerbated by any further appreciation of the won against the dollar. Korea had the same motive to keep the won from becoming overvalued, or slow its appreciation down, as did China and Japan; namely to sustain the exports that underpinned its recent economic growth. The won was trading up in 2003 and hurting Korean export competitiveness. The appreciating currency in 2004 continued to cause worry to the large manufacturing firms.

One of the important reasons behind the buoyant export performance was the recovering global economy, which generated a strong demand for Korean products, particularly for electronics, semiconductors, cars and wireless communication devices. Export performance in 2004 was expected to continue to be as good as that in 2003, but exporters complained of the won's appreciation vis-à-vis the dollar as a serious negative factor hindering the competitiveness of exports. ${ }^{19}$ The Korean export sector adjusted its production capacity to the current exchange rate of the won. The continuing depreciation of the dollar caused a good deal more anxiety for the Bank of Korea (BOK) than for the BOJ. Hyundai Motor, Korea's leading car maker, declared a corporate emergency, which it said was caused by the currency appreciation during 2004. It was planning several in-company measures to deal with the currency appreciation. ${ }^{20}$

Owing to the economy's excessive reliance on exports, the BOK was obliged to make more frequent and heavier interventions in the currency markets than the other emerging Asian market economies and Japan. Although contribution to growth by the export sector in Japan was significant, domestic consumer spending made an even stronger contribution. Every time the dollar depreciated, the BOK had to start buying dollars so that the won did not begin rapidly to appreciate. Foreign reserves in the first 15 days of November 2004 increased by $\$ 7.7 \mathrm{bn}$, indicating $\mathrm{BOK}$ purchases of US dollars. This was a new record for intervention by the $\mathrm{BOK}$. As the won is not an international currency and it is not used regionally, the hedging 
techniques of the BOK against currency movements were not as advanced as those used by the BOJ. Hence, the BOK had to intervene in the currency market more frequently than did the BOJ.

The fact that domestic demand remained flaccid in Korea is partly explained by the fact that the won was kept too low by the interventions of an enthusiastic BOK. The won appreciated by 14 per cent against the dollar during the calendar year 2004.

Towards the end of 2004, Korean export growth began to decelerate for reasons other than the won appreciation against the dollar, namely; sluggish DRAM prices in the world markets and a slowdown in China's imports. Under these circumstances, it was not appropriate for the monetary authorities to allow large currency appreciation at this time.

The flip side of this coin is that an appreciating won did have some benefits for the Korean economy. First, it could help Korea in paying off its foreign debt of over $\$ 120 \mathrm{bn}$. Secondly, it could enable the BOK to ward off inflation, which was showing some signs of rising. The principal driving forces of inflation were high oil and industrial raw materials prices. The rate of inflation could not be expected to be high because of almost lifeless domestic demand. Thirdly, a stronger currency would not only make the imports of oil on which Korea depends heavily less costly, but could also stimulate the domestic sector. Fourthly, currency appreciation would help in pursuing import deregulation more aggressively. It would also encourage consumers to purchase imported goods and, more importantly, address problems in one of the weakest areas of the economy, namely, small- and medium-sized enterprises. Many of these firms were not able to afford to import the intermediate inputs necessary for their businesses. ${ }^{21}$ The Korean economy had not been allocating productive resources evenly among the export, import, corporate and household sectors. After the crisis, there was an institutional bias towards allocating capital for production, particularly to the export sector. As opposed to this, its consumption bias is towards domestically produced goods. If these biases are not handled, Korea 'could face the Japanese dilemma of having both a strong currency and weak economic performance'. ${ }^{22}$

\section{CONCLUSIONS AND SUMMARY}

Already high and growing twin deficits created a selling pressure on the dollar. It peaked in February 2002 and was followed by a long dollar correction period, which is still continuing. The candid and first-ever admission of weaknesses in the US economy by the Fed Chairman had an immediate impact: the dollar again went into sharp depreciation vis-à-vis all the major currencies on 20th November, 2004, albeit in an uneven manner. Owing to frequent and intense intervention in the currency markets by Asian central banks, foreign exchange reserves at the world's central banks nearly doubled in a short time span. The weakness of the US dollar was continuously exerting upward pressure on the Asian currencies. This pressure intensified in 2003 and went on increasing in 2004. For the first time since the Asian 
crisis, upward pressure was felt by the Asian currencies.

Asian central banks were averse to currency appreciation and were trying to resist it. After four successive recessions and a prolonged period of deflation, the concern of the BOJ regarding exports was valid. Japan was anxious to hold down the appreciation of the yen to keep its exports competitive in the global market place, particularly in the Eurozone. The yen was, however, allowed to appreciate gradually after the G-7 meeting of September 2003. Like a good global citizen, Japan allowed the yen to appreciate.

Contrary to market expectations and speculative pressure, the PBOC did not see any pressing or immediate need to disturb its de facto dollar peg. This peg had served the Chinese economy well since its inception, which made it all the more necessary for the PBOC to be extra cautious regarding switching to a new currency regime. Besides, there was some disagreement over whether the renminbi yuan was undervalued and, if so, by how much. The Chinese economy had several domestic and financial sector problems to cope with before taking tangible measures regarding the currency regime and liberalisation of capital accounts. In February 2005, during the G-7 meeting in London, the PBOC made some overtures to changing its currency regime. Korea had the same motive to keep the won from becoming overvalued, or slow its appreciation down, as did China and Japan, namely to sustain exports that underpinned its recent economic growth, albeit there was a clear difference between Korea and the other two economies. The won did begin to appreciate, although somewhat belatedly and to a lesser degree than the yen.

\section{References}

(1) International Monetary Fund (2004) 'US Fiscal Policies and Priorities for Long-Run Sustainability', IMF, Washington DC, January.

(2) Gale, W. G. and Orszag, P. R. (2004) 'The US Budget Deficit: On an Unsustainable Path', The Brookings Institution, Washington, DC, December.

(3) Organization for Economic Cooperation and Development (2004) 'OECD Economic Outlook', No. 76. Paris, France, 30th November.

(4) Roubini, N. and Setser, B. (2004) 'The US as a Net Debtor: The Sustainability of the External Imbalances', November. Available on the internet at http://www.stern.nyu.edu/ globalmacro/Roubini-Setser-US-Externalimbalances.pdf; accessed on 1st January, 2005.

(5) Houthakker, H. S. and Magee, S. L. (1969). 'Income and price elasticities in world trade', Review of Economic and Statistics, Vol. 51, No. 1, pp. 111-125.

(6) Summers, L. H. (2004) 'The US Current Account Deficit and Global Economy', The Per Jacobson Lecture, The Per Jacobson Foundation. Washington, DC, 3rd October.

(7) McKinnon, R. I. (2004) 'Are federal fiscal deficits accelerating deindustrialization in the United States?' The New York Times, 20th October, p. 16.

(8) Morgan Stanley (2004) 'How to Fix the World: Looking to 2005', Morgan Stanley: Global Economic Forum, New York, NY, 17th. December.

(9) Obstfeld, M. and Rogoff, K. (2004) 'The Unsustainable US Current Account Position Revealed', NBER Working Paper No. 10869, National Bureau of Economic Research, Cambridge. MA.

(10) Goldman Sachs (2004) 'A year after Dubai: G-7 still faces an unbalanced world', Global Economics Weekly, 2nd September.

(11) Mann, C. L. (2004) 'Managing exchange rates: Achievement of global re-balancing or evidence of global codependancy', Business Economics, Vol. 39, No. 3, pp. 19-29.

(12) Rajan, R. (2004) 'Credible policies will break the dollar's fall'. Financial Times, 15th December, p. 12 . 
(13) Baker, M. and Jen, S. L. (2004) 'Asian Currencies: Rotation Revived', Morgan Stanley: Global Economic Forum, 29th November.

(14) Dooley, M. P., Folkerts-Landau, D. and Garber, P. (2003) 'An Essay on the Revived Bretton Woods System', NBER Working Paper No. w9971, National Bureau of Economic Research, Cambridge. MA, September.

(15) Dooley, M. P., Folkerts-Landau, D. and Garber, P. (2004) 'The US Current Account Deficit and Economic Development: Collateral for a Total Return Swap', NBER Working Paper No. 10727, September, National Bureau of Economic Research, Cambridge, MA.

(16) Xie, A. (2004) 'Asia Can Defend Itself, Morgan Stanley: Global Economic Forum, 29th November, pp. $4-5$.

(17) International Monetary Fund. (2003) 'World
Economic Outlook', IMF, Washington, DC, September.

(18) Pesek, W. (2004) 'China Tells Currency Speculators to Get Lost', available at http://quote.bloomberg.com/apps/news?pid= 10000039\&refer $=$ columnist_pesek\&sid= aDaFXG_.Fn08, accessed 15th December, 2004.

(19) Jeon, J-K. 'A Macroeconomic Overview of the Korean Economy', The Korea Economic Institute, Seoul.

(20) Anon. (2004) 'Business: rising won takes a toll', Seoul Times, 17th December, p. B-6.

(21) Anon. (2004) 'Asian currencies: A need for flexibility', Economist, 27th November, pp. 75-76.

(22) Xie, A. (2003) 'Korean Economy: Containing the Won?' Morgan Stanley: Global Economic Forum, 12th June, pp. 3-4. 